\title{
A STUDY ON THE ACTION OF TWO CALCIUM CHANNEL BLOCKERS (VERAPAMIL AND FLUNARIZINE) UPON AN EXPERIMENTAL MODEL OF TARDIVE DYSKINESIA IN RATS
}

\author{
JOAO S. PEREIRA * - PAULO H. P. BERTOLUCCI ** - HENRIQUE B. FERRAZ* \\ $L U I Z$ A. F. DE ANDRADE***
}

\begin{abstract}
SUMMARY - Tardive dyskinesia (TD), a serious complications of neuroleptic chronic use, has no effective therapy yet. We performed an experiment to study the action on $T D$, of the calcium channel blockers (CCB) drugs, verapamil and flunarizine. We obtained the TD model in rats, administering haloperidol for a 21-day period. After this, the stereotyped movement induced by apomorphyne was rated. The CCB drugs were administered in acute (in the 28th. day) and chronic (for 8 days, after the 25th day) experiments. Acutely, verapamil increased the stereotyped behaviour, and promoted a reduction of it in the chronic experiment. The results suggest that CCB drugs should be tested in clinical trials of TD.
\end{abstract}

KEYWORDS: tardive dyskinesia, calcium channel blockers drugs, neuroleptics.

Estudo da ąão de dois bloqueadores de canais de cálcio sobre modelo experimental de discinesia tardia em ratos

RESUMO - A discinesia tardia (DT) é complicação decorrente do uso prolongado de neurolépticos. Até o presente, nenhum tratamento provou ser eficaz na DT. Evidências indiretas apontam para a ação de drogas błoqueadoras de canais de cálcio (BCC) em algumas vias neurais. A ação de duas dessas drogas, verapamil e flunarizina, foi testada em modelo experimental de DT em rato, neste estudo. O haloperidol foi administrado por 21 dias e indução de movimentos estereotipados era obtida no $24{ }^{\circ}$ dia, com a injeção de apomorfina. As drogas BCC foram administradias por uma vez no 28\% dia (experimento agudo) e por 8 dias, após o 25\% dia (experimento crônico). A flunarizina não induziu modificação no padrão de estereotipia dos animais, mas o verapamil levou a aumento no experimento agudo e a diminuiçăo no experimento crónico. Estes achados indicam que as drogas BCC podem ter alguma ação sobre a DT e que ensaios clínicos devem ser feitos para se comprovar se tal ação ocorre no homem. lépticos.

PALAVRAS-CHAVE: discinesia tardia, drogas bloqueadoras de canais de calcio, neuro-

Tardive dyskinesia (TD), a complication of neuroleptic prolonged use, is due to a blockade of striatal postsynaptic dopaminergic (DA) receptors. A chemical denervation occurs and is followed by hypersensitivity of DA receptors. This can be indirectly proven by apomorphine or amphetamine DA agonists acting on postsynaptic receptors and in neurotransmitters release, respectively. Behavioural studies show that an increase in striatal dopaminergic action produces

Sector for Investigation of Extrapyradimal Diseases, Department of Neurology and Neurosurgery, Escola Paulista de Medicina: * Postgraduate in Neurology; ** Associate Professor of Neurology; *** Associate Professor of Neurology and Head of the Sector.

Dr. Henrique Ballalai Ferraz - Disciplina de Neurologia, (Setor de Investigação em Doenças Extrapiramidais), Escola Paulista de Medicina - Rua Botucatu 740 - 04023 São Paulo SP - Brasli. 
stereotyped movements in rats 15,16,23. In spite of all therapeutic trials, no significant improve has been observed in TD. Although, persistent researchers have been trying to find efficacious alternatives $1,9,10$.

Recent studies have demonstrated side effects of calcium channel blockers (CCB) upon the CNS. Acathysia, depression, parkinsonism and dyskinesia, all secondary to flunarizine chronic use $7,18,19,20$ as well as dysgeusia and dysosmia 17 induced by nifedipine may be evidences that these drugs act on neurotransmission. The influence of such drugs on DA system (more precisely, the nigrostriatal system), brought us to set up a behavioural study by means of an experimental model of TD in rats, making use of verapamil and flunarizine, pharmacologically distinct calcium channel blockers 13,25 .

\section{MATERIAL AND METHODS}

Animals - Male Wistar rats aged between 3 and 4 months were used, and kept in cages in 5-animal groups in a bioterium under lighting and temperature controlled conditions.

Drugs - Solutions of $5 \mathrm{mg} / \mathrm{ml}$ haloperidol, $2 \mathrm{mg} / \mathrm{ml}$ apomorphine, $2 \mathrm{mg} / \mathrm{ml}$ verapamil prepared with distilled water, and a flunarizine suspension prepared with $2 \% \mathrm{Tween}$ (v/v). The drugs were administered intraperitoneally (i.p.) in a volume of $1 \mathrm{ml} / \mathrm{kg}$.

Stereotyped behaviour - The rats underwent a 21-day treatment with haloperidol, being kept in 5-animal cages. Apomorphine was given on the 24th day of the experiment, for the stereotyped movement testing. In the acute protocols the test was carried out on the 28 th day, and he calcium channel blocker or a control solution was given 20 minutes before apomorphine. Chronic protocols were carried out with apomorphine exclusive administration on the day of testing. In the provocative test, as well as in the experimental test, the animals were placed in individual cages for the grading of duration and intensity of stereotyped movement. Then, each animal was observed every 5 minutes for 30 seconds, according to a stereotyped grading scale, adopted for use at the Department of Psychobiology, Escola Paulista de Medicina (Tablie 1). The experiment was deemed terminated whenever the animal onde again presented with normal exploratory reactions, establishing grooming as a criterion for finishing the test.

Technique:

Acute testing - Eighty rats were treated for 21 days with haloperidol $5 \mathrm{mg} / \mathrm{kg}$ i.p., and were divided into 8 groups with 10 animals each. On the 24 th day of the experiment apomorphine was administered i.p., $2 \mathrm{mg} / \mathrm{kg}$, as a provocative test for stereotyped movements. On the 28th day, an experimental test with calcium channel blockers was set up.

Experiments with verapamil: verapamil was administered i.p. in 2, 4 and $8 \mathrm{mg} / \mathrm{kg} \mathrm{doses}$, as well as saline solution $0.9 \%$ as a control. After 20 minutes, apomorphine $2 \mathrm{mg} / \mathrm{kg}$ was given i.p. Stereotyped behaviour was evaluated as described above.

Experiments with flunarizine: flunarizine was administered i.p. in 1.5, and $6 \mathrm{mg} / \mathrm{kg}$ doses, as well as a Tween $2 \%$ suspension as a control. After 20 minutes, apomorphine $2 \mathrm{mg} / \mathrm{kg}$ was given i.p. Stereotyped behaviour was evaluated as described above.

Chronic testing I - Sixty rats were treated for 21 days with haloperidol $5 \mathrm{mg} / \mathrm{kg}$ i.p., and were divided into 6 groups with 10 animals each. On the 24th day of the experiment apomorphine was administered i.p., $2 \mathrm{mg} / \mathrm{kg}$, as a provocative test for stereotyped movements. From the 25th day on, CCB were administered.

Experiments with verapamil: verapamil was administered i.p. from the 25th to the 32nd day, in 4 and $8 \mathrm{mg} / \mathrm{kg}$ doses, as well as saline solution $0.9 \%$ as a control. Apomorphine $2 \mathrm{mg} / \mathrm{kg}$ was administered i.p. on the 32nd day of the experiment, followed by the evaluation of stereotyped behaviour as already described.

Experiments with flunarizine: flunarizine was administered i.p. from the 25th to the 31st day, in 3 and $6 \mathrm{mg} / \mathrm{kg}$ doses, as well as a Tween 2\% suspension as a control. Apomorphine $2 \mathrm{mg} / \mathrm{kg}$ was administered i.p. on the 32nd day of the experiment, followed by the evaluation of stereotyped behaviour as calready described. 
Chronic testing II - Sixty rats were divided into 6 groups with 10 animals each, and were treated for 21 days with haloperidol $5 \mathrm{mg} / \mathrm{k}$ i.p. associated to CCB.

Experiments with verapamil: the drug was administered i.p. in 4 and $8 \mathrm{mg} / \mathrm{kg}$ doses, as well as saline $0.9 \%$ as a control, in association with the neuroleptic. On the 24th day of the Experiment an experimental test with apomorphine $2 \mathrm{mg} / \mathrm{kg}$ i.p. was carried out, followed by the evaluation of stereotyped behaviour as already described.

Experiments with flunarizine: the drug was administered i.p. in 3 and $6 \mathrm{mg} / \mathrm{kg}$ doses, as well as a Tween $2 \%$ suspension as a control, in association with the neuroleptic. On the 24 th day of the experiment an experimental test with apomorphine $2 \mathrm{mg} / \mathrm{kg}$ i.p. was carried out, followed by the evaluation of stereotyped behaviour as already described.

Statistical analysis - It was obtained through the tests of Kruskall-Wallis and MannWhitney, based on the median of grades, calculated by the medians of grades in each group, as well as the median of maximal grades, which arose from the highest grade of stereotyped novement given to each animal of the group. The significance level was $5 \%(p<0,05)$.

\section{RESULTS}

Effect of acute administration of calcium channel blockers verapamil and flunarizine on stereotyped behaviour, under apomorphine induction: A tendency was observed in acute experiments with verapamil to an increase in the stereotyped behaviour $\left(H_{(3)}=15.67 ; p<0.01\right)$, as analysed through the median of grades. The same did not happen when analysis was performed through the median of maximal grades $\left(\mathrm{H}_{(3)}=0.80\right)$ (Table 2). In the experiments with flunarizine no statistically significant deviations occurred $\left(\mathrm{H}_{(3)}=3.02\right.$, and $\left.\mathrm{H}_{(3)} \max =1.92\right)$.

Table 1. Stereotyped behaviour grading scale adopted for use at the Department of Psycho. biology, Escola Paulista de Medicina.

\begin{tabular}{cl} 
Grade & Type of behaviour \\
\hline 0 & $\begin{array}{l}\text { Normal exploratory behaviour } \\
1\end{array}$ \\
2 & Funks interruptedly \\
3 & Funks continually \\
4 & Licks and/or false bites, continually \\
5 & Licks and/or false bites continually, and bites interruptedly \\
6 & Bites continually, while moving about \\
7 & Bites continually, wihtin a small area, without moving
\end{tabular}

Table 2. Results of stereotyped movement intensity in every animal group, expressed through the medians, under verapamil and apomorphine acute action.

\begin{tabular}{ccc}
$\begin{array}{c}\text { Group } \\
\mathrm{n}=10\end{array}$ & $\begin{array}{c}\text { Intensity of stereotyped movements } \\
\text { Grade } \\
\text { Maximal grade }\end{array}$ \\
\hline Control & 2.75 & 5.0 \\
Verapamil (2mg) & $3.5 *$ & 5.0 \\
Verapamil (4mg) & 3.0 & 4.5 \\
Verapamil (8mg) & $4.0 *$ & 5.0 \\
\hline
\end{tabular}

Test of Mann-Whitney: control vs verapamil.

* $p<0.02$, in relation to control. 
Effect of chronic administration of $\mathrm{CCB}$ verapamil and flunarizine on stereotyped behaviour, under apomorphine induction:

Chronic testing I - A reduction of stereotyped movements was observed in the experiments conducted with chronically administered verapamil under apomorphine induction, as analysed through the median of grades $\left(\mathrm{H}_{(2)}=7.12 ; \mathrm{p}<0.05\right)$ and the median of maximal grades $\left(\mathrm{H}_{(2)} \max =9.06 ; \mathrm{p}<0.02\right)$ (Table 3$)$. The experiments carried out with flunarizine showed nc statistically significant different behaviour $\left(\mathrm{H}_{(2)}=5.58\right.$, and $\left.\mathrm{H}_{(2)} \max =0.39\right)$.

Chronic testing II - No statistically significant changes in stereotyped behaviour were observed in these experiments, with verapamil administration $\left(\mathrm{H}_{(2)}=2.65\right.$, and $\left.\mathrm{H}_{(2)} \max =1.77\right)$.

Table 3. Results of stereotyped movement intensity in every animal group, expressed through the medians, under apomorphine induction after verapamil chronic administration.

\begin{tabular}{ccc}
$\begin{array}{c}\text { Group } \\
\mathrm{n}=10\end{array}$ & $\begin{array}{c}\text { Intensity of stereotyped movements } \\
\text { Grade } \\
\text { Maximal grade }\end{array}$ \\
\hline Control & 5.0 & 5.0 \\
Verapamil (4mg) & 5.0 & 6.0 \\
Verapamil (8mg) & $3.0 *$ & $4.0 * *$ \\
\hline
\end{tabular}

Test of Mann-Whitney: control vs verapamil.

$* p<0.02 ; * * p<0.05$.

\section{COMMENTS}

Experimental studies with animals are useful tools in the study of TD despite the limitation of not replicate exactly what happens to man. All models involve chronic neuroleptic administration that, in the end, will lead to an increase in the stereotyped behaviour induced by DA agonists. This behaviour can be shortly obtained in animals through 3-week use of neuroleptics followed by the administration of dopaminergic agonists for some days after neuroleptic withdrawal 4, $15,16,23,28$. The number and affinity of striatal DA receptors are increased in the experimental TD models employing rats treated with neuroleptics $3,5,14$.

CCB seem to mimick the effects of extracellular deprivation of calcium. Calcium ion is important in several biological processes, including cellular metabolism and neurotransmission. Reactions involving calcium in the homeostasis take place in specific proteins that bind to the ion inhibiting or activating enzymes involved in different processes, some of which still obscure 24,25 .

In our experiments we attempted to show the action of verapamil and flunarizine, pharmacologically distinct $C C B 13,25$, in the hypersensitization of postsynaptic striatal DA receptors, manifested through the stereotyped behaviour of the animals. These substances were acutely and chronically employed by us; in the last case we noted their actions in association with haloperidol, and after hypersensitization of postsynaptic striatal receptors by the neuroleptic.

Acute administration of verapamil, in the doses adopted in our experiments, do demostrate an increase in stereotyped behaviour in the animals. This could be resulted from a mechanism of action other than its known CCB action. It could still be acting synergistically with apomorphine in the DA system. In the doses employed by us, which are relatively low in relation to other studies, verapamil might be interacting with presynaptic receptors in a similar way to DA antagonists. It is known that low concentrations of these drugs increase the release of dopamine, due to the action on auto-receptors, which are calcium-dependent. DA agonists reduce this release, while antagonists increase it 27.

The effects of chronically administered verapamil, after hypersensitization of postsynaptic DA receptors seem to be evident. The reduction of stereotyped 
behaviour in rats may suggest that this substance have cumulative properties on DA receptors and, in consequence, could reduce receptor hypersensitivity to the neurotransmitter manifested by stereotyped behaviour. This may result from the development of subsensitivity at the DA receptor, induced by the CCB, or even by another mechanism different from its action on calcium channels.

Studies employing rabbit hypothalamus have shown an increase on norepinephrine release, under low concentrations of verapamil, resulting from a blockade to auto-receptor due to specific properties of antagonism to alpha-2 adrenoreceptor 8 . Low verapamil doses administered to a TD model in rats did not show any effect on stereotyped behaviour 6,21 while high doses suppressed both hyperkinesia and dyskinesia in these animals 6 . At high concentrations, verapamil tends to inhibit the release of dopamine and acetylcholine in the CNS, by blocking striatal DA receptors 26 .

Despite its inhibitory effect upon stereotyped behaviour when chronically used after hypersentization of postsynaptic striatal DA receptors, if verapamil is given along with haloperidol, it does not prevent the development of receptor hypersensitivity resulting from neuroleptic prolonged use. Although we did not observed the influence of verapamil on stereotyped behaviour in rats, other studies have shown different actions for this CCB. Chronic high dose use of verapamil or dilthiazem along with haloperidol administration for 28 days in rats, prevented the development of behavioural hyperactivity under apomorphine use; nevertheless, the same was not verified with nifedipine use 12 .

Flunarizine testing did not show any influence on stereotyped behaviour in the animals, in the employed doses. Yet, other protocols using high acute doses of flunarizine and nifedine in mice showed reduced behavioural hyperactivity in responses to amphetamine. Consequently, one cannot state that this drug has no effect on TD; maybe at higher doses this can be demonstrated.

CCB can decrease calcium utilization during the process of cellular activation. This may point to an important role for calcium in $\mathrm{TD}$, since the ion is necessary for some metabolic processes, and for neurotransmission.

Some investigators have shown a reduction of dyskinetic movements in schizophrenic patients presenting wit TD secondary to neuroleptic use, by the use both of verapamil ${ }^{2}$ and dilthiazem 22 . This could be a demonstration of the effect of CCB substances upon TD. As all therapeutic trials have not so far offered any efficacious treatment of TD, CCB substances might prove to be a new choice to solve the problem.

Acknowledgments - We are grateful to the Department of Psychobiology of Escola Paulista de Medicina for allowing us to use their facilities (animals, laboratories and technical personal).

\section{REFERENCES}

1. Andrade LAF, Bertolucci PHF, Pereira JS. Discinesia tardia: fisiopatologia e tratamento. Arq. Neuro-Psiquiat (São Paulo) 1984, 42:362-370.

2. Barrow N, Childs A. An anti-tardive-dyskinesia effect of verapamil. Am $J$ Psychiatry 1986, 143:1485.

3. Borison RL, Hitri A, Blowers AJ, Diamond BI. Antipsychotic drug action: clinical, biochemical, and pharmacological evidence for site specificity of action. Clin Neuropharmacol 1983, $6: 137-150$.

4. Bruin VMS. Estudo da ação de um bloqueador de canais de cálcio (nifedipina) em um modelo experimental de discinesia tardia no rato. Tese de Mestrado, Escola Paulista de Medicina. São Paulo, 1985.

5. Burt DR, Creese I, Snyder SH. Antischizophrenic drugs: chronic treatment elevates dopamine receptor binding in brain. Science 1977, 196:326-328.

6. Cadet JL, Rothman RB. Decreased striatal opiate s-receptors in the rat model of persistent dyskinesia induced by iminodipropionitrille. Neurosci Lett 1986, 72:84-86.

7. Chouza C, Camaño JL, Aljanati R, Scaramellia A, De Medina O, Romero S. Parkinsonism, tardive dyskinesia, akathisia and depression induced by flunarizine. Lancet 1986, 1:13031304. 
8. Galzin AM, Langer SZ. Presynaptic alpha2-adrenoceptor antagonism by verapamil but not by dietiazem in rabbit hypothalamic slices. $\mathrm{Br} \mathrm{J}$ Pharmacol 1983, 78:571-577.

9. Gerlach J. Tardive dyskinesia. Dan Med Bull 1979, 26:209-245.

10. Goetz CG, Weiner WJ, Nausieda PA, Klawans HL. Tardive dyskinesia: pharmacology and clinicial implications. Clin Neuropharmacol 1982, 5:3-22.

11. Grebb JA. Nifedipine and flunarizine block amphetamine-induced behavioral stimulation in mice. Life Sci 1983, 38:2875-2381.

12. Grebb JA, Shelton RC, Freed WJ. Diltiazem or verapamil prevents haloperidol-induced apomorphine supersensitivity in mice. $J$ Neural Transm 1987, 68:241-255.

13. Greenberg DA. Calcium channel antagonists: pharmacology and neurological applications In Appel SH (ed.): Current Neurology, Vol, 6. Chicago: Year Book Med Publ, 1986, p 91-121.

14. Hitri A, Weiner WJ, Borison RL. Diamond BI, Nausieda PA, Klawans HL. Dopamine binding following prolonged haloperidol pretreatment. Ann Neurol 1978, 3:134-140.

15. Klawans HL, Rubovits R. An experimental model of tardive dyskinesia. J Neural Transm. 1972, $33: 235-246$.

16. Klawans HL, Goetz CG, Carvey P. Animal models of tardive dyskinesias. Clin Neuropharmacol 1983, 6:129-135.

17. Levenson JL, Kennedy K. Dysosmia, dysgeusia and nifedipine. Ann Interm Med 1985, $102: 135-136$

18. Melo-Souza, SE. Flunarizina, parkinsonismo e depressão. In Congresso Brasileiro de Neurologia 11\%, Goiânia, 1884: Informações, Programas, Resumos. Goiânia, 1984, p. 39.

19. Meyboom RHB, Ferreira MD, Dieleman BP. Parkinsonism, tardive dyskinesia, akathisia and depression induced by flunarizine. Lancet 1986, 2:292

20. Micheli F, Pardal MF, Gatto M, Torres M, Paradiso G, Parera IC, Giannaula R. Flunarizine and cinnarizine induced extrapyramidal reactions. Neurology 1987, 37:881-884.

21. Renwart N, Frances H, Simon P. Verapamil s lack of dopaminergic properties in mice. Am J Fsychiatry 1986, 143:933-934.

22. Ross JL, Mackenzie TB, Hanson DR, Charles CR. Diltiazem for tardive dyskinesia. Lancet 1987, 1:268.

23. Rubovits $\mathrm{R}$, Klawans HL. Implications of amphetamine-induced stereotyped behavior as a model for tardive dyskinesias. Arch Gen Psychiatry 1972, 27:502-507.

24. Spedding M. Assessment of Ca2+-antagonist efiects of drugs in $\mathbf{K}+$-depolarized smooth muscle. Arch Pharmacol 1982, 318:234-240.

25. Speciding M, Cavero I. Calicium antagonists: a class of drugs with a bright future. Part II: Determination of basic pharmacological properties. Life Sci 1984, 35:585-587.

26. Starke K, Spath L, Wichmann T. Effects of verapamil, diltiazem and ryosidine on the relcuse of copamine and acetylchoine in rabbit cauate nucleus slices. Arch Pharmaco $1984,325: 124-130$.

27. Tepper JM, Groves PM, Young SJ. The neuropharmacology of the autoinhibition of moncamine release. Trends Pharmacol Sci 1985, 6:251-256.

28. Weiner WJ, Carvey P, Nausieda PA, Goetz CG, Klawans HL. Effect of chronic levodopa on haloperidol-induced behavioral supersensitivity in the guinea pig. In Friednoff AJ, Crase TN (eds): Advances in Neuro'ogy, Vol. 35. New York: Raven Press, 1982, p 213-219. 